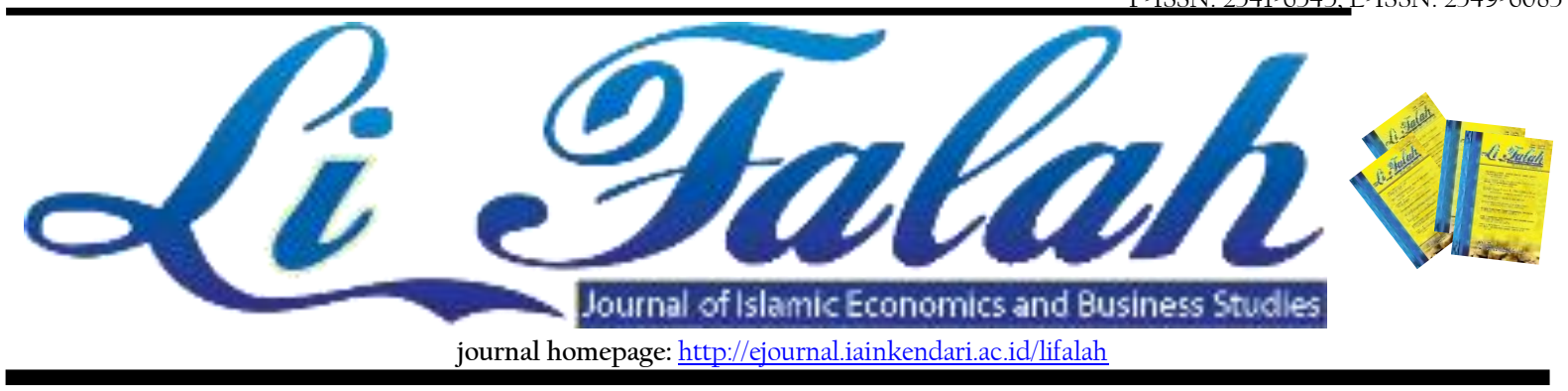

\title{
The Role of Islamic Economic Institutions to Recover Real Sector of SMEs During COVID-19 Pandemic
}

\author{
Trimulato ${ }^{1}$, Nasrullah Bin Sapa ${ }^{2}$, St. Hafsah Umar ${ }^{3}$ \\ 1,2,3 Departement Of Sharia Banking Universitas Islam Negeri Alauddin Makassar, South Sulawesi, Indonesia \\ email: *Itri.mulato@uin-alauddin.ac.id, nasrullah.sapa@uin-alauddin.ac.id, hafsah.umar@uin-alauddin.ac.id
}

\begin{tabular}{|c|c|}
\hline ARTICLE INFO & A B S T R A C T \\
\hline \multirow{11}{*}{$\begin{array}{l}\text { Article History: } \\
\text { Received } 10 \text { March } 2021 \\
1^{\text {st }} \text { Received in revised form } 5 \\
\text { April } 2021 \\
2^{\text {st }} \text { Received in revised form } 26 \\
\text { May } 2021 \\
3^{\text {st }} \text { Received in revised form } 15 \\
\text { June } 2021 \\
\text { Available online } 30 \text { Juni } 2021\end{array}$} & Islamic economics prioritizes the real sector, including SMEs, and makes \\
\hline & Islamic Economic institutions supporters and drivers. The market share of \\
\hline & sharia financial has reached 8.5 percent and will continue to grow and develop. \\
\hline & Since the emergence of the coronavirus outbreak, it has eroded and slowed \\
\hline & down economic activity, including in the SMEs sector. SMEs are among the \\
\hline & ones that have been significantly affected by the coronavirus. To restore the \\
\hline & economic activities of SMEs, the Islamic Economic Institutions have a role in \\
\hline & restoring the economic activities of SMEs. This study aims to determine the \\
\hline & development of Islamic economic institutions, and this type of research is \\
\hline & $\begin{array}{l}\text { library research with qualitative characteristics. Sources of data in this } \\
\text { research are secondary data sourced from several institutions that have been }\end{array}$ \\
\hline & presented. The limitation of this study is only for a few Islamic economic \\
\hline \multirow{4}{*}{$\begin{array}{l}\text { Keywords: } \\
\text { Islamic Economic Institutions, } \\
\text { SMEs, and Covid-19 }\end{array}$} & institutions related to SMEs. The data analysis technique used in this research \\
\hline & is descriptive qualitative. Describing the object of research on the development \\
\hline & of Islamic economic institutions and the role of Islamic economic institutions \\
\hline & to recover the real sector of SMEs is included in the analysis technique. The \\
\hline \multirow{11}{*}{$\begin{array}{l}\text { http://dx.doi.org/10.31332/lif } \\
\text { alah.v6i1.2653 }\end{array}$} & results of this study indicate the development of Islamiceconomic institutions. \\
\hline & Sharia Financing Banking (BPRS) grew by 349.34 for income, Sharia \\
\hline & Microfinance Institutions (LKMS) grew by 11.75 percent for financing, \\
\hline & $\begin{array}{l}\text { Sharia Peer To Peer Lending (P2P) institutions experienced a decrease in } \\
\text { assets by } 0.05 \text { percent. Social institutions, the growth of social fund collection }\end{array}$ \\
\hline & was 48.08 percent at Insisatif Zakat Indonesia (IZI), and the growth in \\
\hline & distribution of social funds by 114.27 percent Badan Amil Zakat Nasional \\
\hline & $\begin{array}{l}\text { (BAZNAS). The role of Islamic economic institutions in the recovery of the } \\
\text { real sector of SMFs amid the Covid-19 outbreak namely ontimizino finance }\end{array}$ \\
\hline & for SMEs, assisting financing customers, providing relief for affected \\
\hline & customers, participating in marketing customer products online, maximizing \\
\hline & $\begin{array}{l}\text { profit-sharing system, strengthening partnerships, and maximizing the } \\
\text { distribution of social funds for SMEseconomic activities. }\end{array}$ \\
\hline & \\
\hline
\end{tabular}

\section{Introduction}


Islam is the perfect religion that regulates all aspects of human life, whether Mahwah worship, human relationship with Allah's creator, or muamalah worship, which governs humans' relationship. One of the things regulated in Islam today is economics, some of which are heard more often, discussed more frequently, and are increasingly in demand these days. Every human being always wants his life in this world to be in a happy state, both materially and spiritually, individually and socially. However, in practice, multi-dimensional happiness is complicated to achieve because of the limited ability of humans to comprehend and interpret their desires comprehensively, limitations in balancing aspects of life, and limited resources that can be used to achieve this happiness. Economic problems are only one aspect of life expected to bring humans to their life goals (P3EI UII., 2008).

To find out whether a speech or action is loved and blessed by Allah or not, we must refer to the Quran and as-sunnah, based on the guidance of the ulama ahlus sunnah waljama'ah, not based on their own opinions or volition. And it must be remembered that these words and actions are done sincerely, expecting only the pleasure of Allah. Including the matter of mu'amalah, it has been arranged to avoid prohibited things. Muamalah with the notion of social life where everyone acts in a relationship with other people, which creates a connection of rights and obligations, which is the most significant part of human life. Muamalah activity of the relationship between humans and other humans. A narrower understanding of muamalah is an economic activity related to management and business. The development of Islamic economics must be fought for, not only in terms of content and object but also in terms of the subject of the perpetrators. The actors of the sharia economy must be every Muslim who understands the essence of the Islamic economic system and physically and mentally struggles to uphold Allah's laws, especially in the economic field. Among the tips to get closer to Allah for sharia economic actors is always to increase the values of belief and faith (Fahmi, 2014).

Islamic law guides its followers on the basic principles in the economic behavior of individuals leading to general goals (maqashid al-Syariah), which is to realize the well-being of society. From there, Islam provides ample space for scholars to conduct severe and in-depth studies in many fields, including the study of Islamic economics, to select appropriate strategies for the existing stages of economic and social development. Islamic law provides space for contextualization (ijtihad) by not committing essential violations. The study so that Islam becomes productive (Empirical Islam). Islamic treasures offer space for Muslim scholars to conduct in-depth analyses to develop maslahah Islamic knowledge. (Minarni., 2015).

The Islamic economy is built based on Islam. Therefore it is an integral part of Islam. Islam's derivation, Islamic economics will follow Islam in various aspects. Islam is a system of life (way of life) that will lead man to something better by the purpose of his life. The Islamic economy was built for a sacred purpose, guided by the teachings of Islam and achieved in ways determined by the teachings of Islam. Therefore, all these things are interconnected and hierarchically structured because the spirit of Islamic economics is reflected in its purpose and supported by its pillars. The goal to achieve falah can only be realized with Islamic economic pillars, namely the fundamental values (Islamic values) and operational pillars, which are reflected in the principles of Islamic economics. From here, you will see an Islamic economic building in a paradigm, both the paradigm in thinking and behavior and its economic form. (P3EI UII. 2008).

In the Islamic view, the existence of human life is inseparable from the instinct of human life brought from birth consists of 3 things, namely: Instinct of self-defense (ghorizatul baqa), the instinct of self-defense for survival given by God to all living beings, including human beings. The instinct to carry offspring (ghorizatun nau'), the instinct to have offspring, is given by Allah to all living beings the same as the instinct of self-defense. Religious instinct (ghorizatun taddayun), religious instinct is only given to God's creation, the best creature on earth named human. The proof that man has a religious instinct is when there is a terrifying condition, and then there is a terrifying condition in the heart. In the heart, say the existence of the Almighty on this earth and ask for protection from Him. (Gita. 2006) 
Indonesia is a country with the largest Muslim population in the world. Ideally, it has an excellent opportunity to become a place for halal product development, including Islamic economic thoughts. With a large population, Indonesia can become a laboratory for developing Islamic economic science. However, this can be realized if Islam has become a way of life, including decisions in the economic field. Seeing the potential of halal products and services in the world, the potential for sharia business in Indonesia is still enormous, seeing the many possibilities that are well tapped. For this reason, Indonesia still needs to increase further understanding and awareness of halal products and services and the halal lifestyle within the government. (Riyanto. 2011)

Sharia-based businesses in this country seem to be starting to grow. This growth is evident in the financial sector. We have recorded Islamic commercial banks, Sharia BPR, and Baitul Maal Wattamwil. This institution has millions and even billions of rupiah in public funds by sharia principles. Such financial institutions must operate strictly based on sharia principles. This principle is very different from the principles adopted by non-Islamic financial institutions. The principles and trade principles are; prohibition of applying interest to all forms and types of transactions. Carrying out business and trade activities based on fairness and lawful profit. Take out zakat from the results of his actions. Prohibition of running a monopoly. Working together in building society through business and trade activities that Islam does not prohibit. From the results of the deliberation (ijma 'international) of Muslim economists and fiqh experts from the Fiqh Academy in Mecca in 1973, it can be concluded that the basic concept of economic relations based on Islamic sharia in the Islamic economic system can be applied in the operations of bank financial institutions and financial institutions. Not a bank. The application of this concept is manifested by the emergence of Islamic financial institutions in the archipelago. (Muhamad. 2009)

Muslims in modern life face quite a challenge. On the one hand, he must keep up with global developments in the economy, science, and technology. Meanwhile, on the other hand, we must adhere to the provisions in sharia. In other words, Muslims must survive in the era of globalization while still guided by sharia values. It isn't easy to get out of the interest-based ribawi economic system in real life, especially in the Muslim economy. (Khotibul and Setiawan. 2015). This challenge is increasingly felt today, where the Covid-19 outbreak has emerged and has dramatically impacted the delay in economic activity. Since the emergence of the covid-19 epidemic, it has cut off many activities of institutions, including Islamic financial institutions. Currently, Islamic financial institutions are also affected by covid-19. Therefore, there needs to be a strategic effort so that Islamic financial institutions can survive and continue to contribute to the economy.

In an Islamic economy, the real sector is the primary sector that must be moved, and the financial industry supports the industry. More specifically, the entire industry is essential in the Islamic economy, considering that the real sector of the type of Micro, Small, and Medium Enterprises (SMEs) is a sector that involves many parties and has a significant portion in the movement to support the economy in our country. It is known that micro-scale enterprises dominate the private sector. This finding also means that there is a lot of public interest in opening a business or becoming an entrepreneur. Next is how to make micro-scale businesses reach a large scale, to improve national economic conditions. Based on the contribution of SMEs to the Gross Domestic Product (GDP) of the sector, it can be seen that the most significant contribution of SMEs is in the Agriculture, Animal Husbandry, Forestry, and Fisheries (PPKP) sector with the UMKM unit of 49.58 percent, followed by the Trade, Hotel and Restaurant sector (PHR) of 29.56 percent. The industry in this sector can be developed from micro, and there is an opportunity to be developed into a large enterprise. (Irfan and Laily. 2016)

SMEs are one of the sectors that have been severely affected due to the Covid-19 pandemic in Indonesia. The Indonesian Minister of Cooperatives and Small and Medium Enterprises (Minister of SMEs), Teten Masduki, said that SME businesses were daily in nature and relied a lot on direct interaction. The restrictions on PSBB and social distancing 
certainly caused demand to drop dramatically. (https:/www.cnbcindonesia.com). The new coronavirus or Corona Virus Disease 2019 (Covid-19) is increasingly felt in the domestic economy, especially in terms of consumption, corporations, the financial sector, and Micro, Small, and Medium Enterprises (MSMEs). Based on a study by the Ministry of Finance, Covid19 poses a threat of losing household income, unable to work to meet their minimum living needs. Especially for the poor and vulnerable and the informal sector. The decline in people's purchasing power is getting higher. For corporations, the economic downturn due to the coronavirus makes manufacturing, trade, transportation, and accommodation sectors such as restaurants and hotels the most vulnerable. Thus, there will be a disruption of business activities that will reduce performance, terminate employment, and even experience the threat of bankruptcy. On the other hand, economic activity and the business world's worsening will spread to the financial sector. Banking and finance companies have the potential to experience liquidity and insolvency problems. Furthermore, the threat of rupiah depreciation, financial market volatility, and capital flights. The Ministry of Finance reviewed the impact of Covid19, which made SMEs unable to carry out their business so that their ability to meet credit needs was disrupted. (https://nasional.kontan.co.id)

The role of financial institutions to distribute assets is, of course, very important. Naman, the concept of Islamic economics, always requires that trends follow the movement of money flows in the real sector. In other words, transactions in the financial industry reflect transactions in the real sector. This fact is very different from the existing concept in the conventional economic system, which places the financial market parallel to the real sector market. With this concept, it is typical for transactions in the financial sector to have nothing to do with transactions in the real sector (decoupling). This finding has the potential for the same acceleration of growth in the real sector, which could trigger the risk of a bubble. This risk is unlikely to occur in a sharia-based economic system that is implemented correctly and istiqomah. Islamic economics emphasizes that assets have an influential role in facilitating trade, investment, and improvement of social welfare. (Darsono et al. 2017)

In these conditions, SMEs need encouragement and support from all parties to rise again amid the Covid-19 outbreak. Islamic economics can take part in the recovery of the SME's economic sector. The Islamic economic system, which is different from conventional economics, can take advantage of its tools in an Islamic economy, transactions containing usury, gharar, maysir, najsy, and other prohibited illegal transactions not permitted. Islamic economy, which is currently in great demand by the community and uses Islamic economic institutions, can contribute to the recovery of the real sector, especially SMEs. Currently, there are many Islamic economic institutions with various variations of their products. In addition to Islamic banks, Islamic non-bank financial institutions and fintech institutions have also been present. Apart from commercial institutions, the Islamic economy has social institutions, which collect social funds to develop SMEs businesses. All Islamic economic institutions can increase their role in restoring economic conditions amid the covid-19 outbreak.

From the description above, the researcher is interested in conducting more profound research studies on the role of Islamic economic institutions in the recovery of the real sector of SMEs. Thus, this study aims to determine the development of Islamic economic institutions and their role in the recovery of the real sector of SMEs.

Before conducting the research, the researcher tried to review the literature of previous scientific works related to the title being studied concerning Islamic economic institutions and SMEs. Therefore, the results of previous studies need to be put forward as material for comparison with research conducted by the author. The scientific works that are relevant to the topic that the researchers raised include:

At the global economic level, the COVID-19 pandemic has a very significant impact on the domestic economy of the nation-state and the existence of SMEs. The Organization for Economic Co-operation and Development (OECD) report states that this pandemic has implications for the threat of a significant economic crisis marked by the cessation of production activities in many countries and falling public consumption levels. No country can 
predict when the COVID-19 pandemic will end. A simple way to adapt and deal with this pandemic is to prepare short-term and long-term strategies while continuing to hope that a vaccine for the COVID-19 virus will soon be discovered and mass-produced. The short-term policy that can be implemented is financial assistance in soft loans or direct cash assistance involving the government and the private sector. Meanwhile, the long-term strategy focuses on introducing and using digital technology for SMEs and preparing for entering the Industrial 4.0 era. (Aknol, 2020)

Singgih Muheramtohad, in his research entitled The Role of Islamic Financial Institutions in Empowering SMEs in Indonesia. Mention that the characteristics of SMEs are relatively low turnover, have make-shift equipment (traditional/manual), and have a narrower market share. They also need capital to develop a business. This field is what Islamic financial institutions need to fill. In Islamic law, the financing sector for real business is practiced directly by the Prophet and the Prophet's companions, including Sahabat Umar Ibn Khattab. Providing financing to SMEs is more effective because it is allocated directly to the needs of small businesses. Another consideration that the government must consider is that the philosophical foundation of this country is Pancasila. In this case, the state is based on social justice for all Indonesian people. (Singgih. 2017)

In their research, Debby Pramana and Rachma Indrarini entitled Sharia BPR Financing in Improving the Welfare of SMEs Based on Maqashid Sharia. Stated that the analysis results carried out on BPRS Prima Mandiri Pamekasan financing customers showed a relationship between financing and the welfare of BPRS customers. This information is possible because the business results will increase when customers get financing. When business results increase, customers can automatically increase their welfare. Increased welfare can be measured by maqashid sharia, such as increasing zakat, infaq, sadaqah for customers, increasing customer daily consumption, fulfilling the need for education, improving future investment, and customers can develop their business. With the increase in customer welfare, it can be said that BPRS Prima Mandiri Pamekasan has an important role, especially in providing capital. However, the BPRS should also provide counseling or outreach for customers, training in improving skills, managing finances, and the sociology of religion to become better (Permana and Rachma, 2017).

Wahid Wachyu Adi Winarto, in his research, The Role of Fintech in Micro, Small and Medium Enterprises, concluded that there is a role of fintech in financial literacy in SMEs in Pekalongan Batang district and Pemalang district. It can be seen from the average increase in the use of banking products and services, savings and loan cooperatives, and other financial institutions by $6.40 \%$ from before the development of fintech. And the role of fintech in financial inclusion in SMEs in the Pekalongan district, Batang district, and Pemalang district. It can be seen that many SMEs owners have used applications and collaborated with banks and savings and loan cooperatives so that they can provide easy access to various types of financial services for banks and savings and loan cooperatives. Financial institutions can reach all MSMEs to remote areas, and fintech is already open access to business finance that is easier and faster from banking institutions and savings and loan cooperatives. And finally, the role of fintech in financial inclusion in MSMEs is that fintech contributes significantly to the empowerment of SMEs and the local economy. (Wahid, 2020)

Miftahul Khaerani and Marlina Ekawati in their paper entitled Productive Zakat and Its Role in developing UMKM Studies at LAZ el-Zawa UIN Maulana Malik Ibrahim Malang. It states that creative, productive distribution is carried out in the SMEs card Hasan and SMEs mudharabah programs. The amount of productive zakat affects the development of the mustahik micro-business. The higher the productive zakat received by the mustahik, the more the mustahik micro-business grows. The length of business and gender were also found to influence the development of the mustahik industry. It is hoped that LAZ el-Zawa can increase zakat funds for creative, productive purposes for mustahik SMEs so that more SMEs can be assisted so that it is expected to reduce poverty. (Khaerani and Marlina, 2017). 


\section{Literature Review}

\subsection{Islamic Economic Institute}

A bank financial institution provides a meeting between parties who need funds for working capital and investment and those who have excess funds. The ease of banking mediation supports the availability of funds for business, which encourages business expansion and eliminates idle funds. Islamic banks are banks whose working mechanism uses a profit-sharing system, not an exciting tool. Islamic Bank is a banking financial institution whose operations and products are developed based on the Al-Quran and the Sunnah of the Prophet SAW. (Gita. 2006)

Sharia Banking Financing (BPRS) are banks that carry out business activities based on sharia principles and do not provide services in payment traffic. BPRS is a business entity equivalent to a conventional people's credit bank with the legal form of a Limited Liability Company, Regional Company, or Cooperative. (Acharya and Diana. 2005)

The attention of BPRS to the development of the domestic market in SMEs can be seen from the various objectives to be achieved. The goals desired by the establishment of the BPRS are: To improve the economic welfare of the community, especially those with economically weak groups who generally reside in rural areas. Increase employment, especially at the subdistrict level, to reduce the flow of urbanization. Fostering the spirit of Ukhuwah Islamiyah through economic activities to increase per capita income towards an adequate quality of life. Increase the share of the domestic market (domestic economy). (Sumitro. 1996)

The role of BMT is to keep people away from non-sharia economic practices. Actively socializing in the community about the importance of the Islamic economic system. Conducting coaching and funding for small businesses. BMT must take an active role in carrying out its function as a microfinance institution, for example, using mentoring, coaching, counseling, and supervision of the businesses of the message or the general public. And can eliminate bad culture that often occurs in small communities. Namely, dependence on moneylenders or borrowing at interest is a burden to society. BMT must provide better services to the community and provide convenience in financing without procedures that can make it difficult for fund applicants. BMT will maintain the economic justice of society with an even distribution. (Sudarsono. 2008)

Islamic finance is a financial system whose implementation is based on Islamic law (sharia). The formation of this system is based on the prohibition in Islam to lend or collect loans by charging interest on loans (usury) and the prohibition against investing in prohibited businesses (haram), which the conventional system cannot guarantee. A fintech is a software and modern technology-based business that provides financial services. Fintech companies are generally start-up companies that offer financial services and solutions to customers such as mobile payments, money transfers, loans, fundraising, and even asset management. Sharia fintech means financial services and solutions provided by technology companies/fintech start-ups based on Islamic / sharia laws. (Fintech.2017)

Philanthropy is generosity, generosity, or social donations, showing love to humans. This term comes from the Greek language, namely Philos (love) and Anthropos (human), which means the conceptualization of the practice of giving, service, and voluntary association to help others in need as expressions of love. Islam as a religion that is syāmil and kāmil and rahmatan lil'alamin presents itself as a religion with a philanthropic face. This form of philanthropy is extracted from religious doctrines that come from the Koran and Hadith, modified with the intermediary mechanism of ijtihad. The institution of zakat, infaq, alms, and waqf appears. The aim is that these treasures do not only circulate among the rich. Islamic philanthropy can also be interpreted as giving charity based on promoting social justice and benefit to the general public. (Kholis et al., 2013). 
Trimulato et al./Li Falah-Jurnal Studi Ekonomi dan Bisnis Islam, Volume 6 (No.1 2021)2653

\subsection{Micro, Small and Medium Enterprises (SMEs)}

A micro business is a business that is managed by an individual or family or several people who do not have a complete business license (Nizarul, 2014). Another definition put forward by Warkum Sumitro, micro, small and medium enterprises are businesses carried out by a company with a workforce of not more than 50 people (Warkum, 2004). Meanwhile, according to Musa Hubeis, small businesses and micro can be grouped into the following definitions: 1) independent small businesses, namely without using other workers; 2) Small businesses that use the labor of their family members. And 3) Small businesses that have permanent wage labor. Small businesses in this category are often viewed as businesses that face many difficulties, especially those related to weak managerial capabilities, technology, limited capital, human resources, marketing, and product quality. Small business external factors are difficult to overcome, namely unhealthy market structures and the development of foreign companies producing similar products for the same market segment. (Hubeis, 2009) According to law number 20 of 2008, SMEs Micro is a productive business owned by an individual and or an individual business entity that meets the criteria of a micro business as regulated in the law.

These three types of business have their uniqueness. The difference between SMEs is seen from the net worth and total annual sales of productive companies owned by individuals and or business entities that are not more significant subsidiaries (Law No. 20/2008 on SMEs). Microbusinesses have a maximum net worth of IDR 50 million. Top annual sales of IDR 300 million. Meanwhile, small businesses are those that have a net worth between Rp. 50 million - 500 million. Sales in one year reached Rp. 300 million to Rp. 2.5 billion. Meanwhile, mediumsized businesses have a net worth of Rp. 500 million - 10 billion. Annual sales reach IDR 50 billion. The Central Statistics Agency (BPS) classifies firms based on the number of workers. Household businesses have a maximum of 5 workers. Small and medium enterprises have 6 to 19 workers. Medium enterprises have 20 to 29 workers. If there are more than 100 workers, it is classified as a large business that does not include SMEs. (BAPENAS. 2019) 


\section{Research Method}

This type of research used in this research is library research, using data presented previously with various sources that are considered relevant to the research theme. In this case, it is related to Islamic economic institutions and SMEs. The nature of this research is qualitative research. Research that describes the objects of investigation presented in this case is associated with the development of Islamic economic institutions and the efforts of Islamic economic institutions in the recovery of the real sector of SMEs development during the Covid-19 pandemic.

The data source used in this research is secondary data which the researcher then processes. Data that has been presented by several sources, either from references or from certain institutions. In this study, one of the sources presented by the Financial Services Authority (OJK) is then processed by researchers and several other sources deemed necessary. Secondary data sources come from several Islamic economic institutions.

The limitation of this study is that it focuses only on the theme of Islamic economic institutions and SMEs. Islamic economic institutions are limited to institutions that have a lot of contact with SMEs, such as Sharia Financing Banks (BPRS), Baitul Maal Wattamwil (BMT), Fintech Peer To Peer Landing Syariah (P2P lending), and Islamic Social Institutions. Data collection techniques include collecting data sources that are relevant to the research theme. Such as from journals, references, or other sources that have been previously presented. To obtain the data needed to conduct research.

The data analysis technique used is descriptive qualitative. Namely describing the object of research, which is then described in a description of the data obtained. In this case, it represents the development of Islamic economic institutions, the existence of SMEs, and the role of Islamic economic institutions in the recovery of the real sector of SMEs amid the Covid19 outbreak.

\section{Result and Discussions}

\section{Development of Islamic Economic Institutions}

Table 1.1 Development of BPRS for the Period of January - May 2020

\begin{tabular}{|l|l|l|l|l|}
\hline No & \multicolumn{1}{|c|}{ Components } & \multicolumn{1}{c|}{ January 2020 } & \multicolumn{1}{c|}{ May 2020 } & \multicolumn{1}{c|}{ Growth } \\
\hline $\mathbf{1}$ & Third-Party Funds (DPK) & $9.093 .701^{*}$ & $8.863 .759^{*}$ & $-2,53$ \\
\hline $\mathbf{2}$ & Financing & $10.327 .603^{*}$ & $10.530 .960^{*}$ & 1,97 \\
\hline 3 & Income & $134.909^{*}$ & $606.209^{*}$ & 349,34 \\
\hline 4 & Placements with Other Banks & $2.952 .422^{*}$ & $2.127 .167^{*}$ & $-27,95$ \\
\hline 5 & Number of DPK Accounts & 1.628 .004 & 1.663 .746 & 2,19 \\
\hline
\end{tabular}

Source: Financial Services Authority. Sharia Banking Statistics May 2020 (Data Processed) * In Million Rupiah

The data above shows the development of Islamic financial institutions for the Islamic People's Financing Bank (BPRS) from January to May 2020. The most significant growth was in the revenue component, which grew by 349.34 percent. Meanwhile, two pieces experienced a decline, namely Third Party Funds experiencing a drop of -2.53 percent, and the component Placements with other Banks experiencing a decrease of 27.95 percent.

\section{Development of Baitul Maal Wattamwil (BMT) and Islamic Microfinance Institutions}

The World Giving Index states that Indonesia is one of the most generous countries donating cash donations. Even managing Islamic social funds through Islamic philanthropic institutions and mosques has been prevalent. It has become an essential part of the development and creation of prosperity in Indonesia. On the other hand, the Islamic microfinance sector also continues to grow through cooperatives and institutions, especially 
BMT, a pure Islamic microfinance institution born with Indonesian uniqueness with two functions, namely the amil function (Baitul Maal) and the financing function (Baitut Tamwil). However, even though the development and practice of BMT are rampant in Indonesia, marked by the establishment of around 4,500 BMT units throughout Indonesia (PBMT, 2018), there are still many problems and challenges faced by this sector, primarily related to the sustainability of institutions, so that their benefits are alleviating poverty and the independence of the people's economy is not optimal. (https://knks.go.id)

BMT growth is quite significant, where based on data on Venture Capital BMT (PBMT) as a BMT association in Indonesia, around 4,500 BMTs in 2015 served approximately 3.7 million people with assets of around Rp. About 20 thousand people managed Sixteen trillion. Based on the Ministry of Cooperatives and SMEs data, the number of cooperative business units in Indonesia reaches 150,223 business units, of which 1.5 percent of cooperatives are legal entities. The existence of BMT is expected to encourage the micro and small business sector. This information is considered necessary because BMT drives the Indonesian economy. The number of Indonesians who become entrepreneurs in the SMEs sector increases every year. (https://sharianews.com)

Table 2. Development of Islamic Microfinance Institutions for the Period of January May 2020

\begin{tabular}{|l|l|c|c|c|}
\hline No & \multicolumn{1}{|c|}{ Components } & January 2020 & May 2020 & Growth \\
\hline $\mathbf{1}$ & Asset & $467.90^{*}$ & $474.66^{*}$ & 1,44 \\
\hline $\mathbf{2}$ & Placement Of Funds & $295.42^{*}$ & $289.65^{*}$ & $-1,95$ \\
\hline $\mathbf{3}$ & Financing & $20,20^{*}$ & $22,89^{*}$ & 11,75 \\
\hline $\mathbf{4}$ & Accounts Receivable & $86,29^{*}$ & $95,22^{*}$ & 10,35 \\
\hline $\mathbf{5}$ & Number of units & 76 & 76 & 0 \\
\hline
\end{tabular}

Source: Financial Services Authority. Sharia IKNB Monthly Statistics April 2020 (Data Processed) * In Billion Rupiah.

The data above shows the development of Islamic Micro Institutions (LKMS) in the period January to May 2020 that the most significant growth was in the financing component with growth reaching 11.75 percent, while the number of LKMS units did not achieve growth. Then, a component of the LKMS experienced a decline, namely the placement of funds, which reached 1.95 percent.

Table 3. Sharia Peer To Peer Lending Fintech Institution for April 2020

\begin{tabular}{|c|l|c|c|c|}
\hline No & \multicolumn{1}{|c|}{ Components } & December 2019 & April 2020 & Growth \\
\hline $\mathbf{1}$ & Asset & $50,618,571,149$ & $50,591,727,786$ & $-0.05 \%$ \\
\hline $\mathbf{2}$ & Fintech Players & 164 & 161 & $-1,83$ \\
\hline 3 & Registered Sharia Fintech & 11 & 11 & 0 \\
\hline 4 & Licensed Sharia Fintech & 1 & 1 & 0 \\
\hline
\end{tabular}

Source: Services Authority. Fintech Lending Financial for April 2020 (Data processed)

The data above shows the conditions of sharia fintech lending from December 2019 to April 2020. It shows that it has decreased by -0.05 percent in terms of assets. Likewise, fintech actors in general also experienced a decline of -1.83 percent. The number of Islamic fintech companies is 12 , or only 7.45 percent. Consists of 11 registered companies and one licensed company. In terms of development, the number of sharia fintech lending has not increased. Total fintech lending assets in the April period totaled 3,614,528,740,453, and sharia fintech lending contributed 50,591,727,786 or only 1.40 percent. This data shows that the relatively new Islamic fintech lending is still not growing well, and then it also still makes a relatively 
small contribution to the total fintech as a whole. In these conditions, Islamic fintech needs to be encouraged to grow and compete with existing fintech while maintaining sharia principles. The growth of sharia fintech lending, which has not been maximized, opens opportunities for sharia fintech to grow better in the future, especially to offer attractive products to the public. So that people can fulfill their finances without violating the rules of sharia principles. Thus, Islamic fintech will contribute more to the economy going forward. There are 12 registered/licensed sharia fintech companies, namely; PT Ammana Fintek Syariah, PT Dana Syariah Indonesia, PT Danakoo Mitra Artha, PT Alami Fintek Sharia, PT Syarfi Teknologi Finansial, PT Duha Madani Syariah, PT Qazwa Mitra Hasanah, PT Maslahat Indonesia Mandiri, PT Ethis Fintek Indonesia, PT Kapital Boost Indonesia, PT Piranti Alphabet Perkasa, and PT Berkah Finteck Syariah

Some of the 12 sharia fintech companies focus on financing distribution services in the micro-segment and the property (housing) segments in the haj and umrah bureaus. In addition, five sharia fintech companies focus on channeling MSME financing, namely PT. Blessing Fintech Syariah, PT. Qazwa, PT. Kapital Boost, PT. Alami Sharia, and PT. Ammana.

Table 4. Development of Social Institutions / Amil Zakat Institutions, Infaq, Shadaqah, and Endowments (ZISWAF)

\begin{tabular}{|c|c|c|c|c|c|}
\hline No & $\begin{array}{l}\text { Name of the } \\
\text { ZISWAF } \\
\text { Institution }\end{array}$ & Component & 2017 & 2018 & Growth \\
\hline 1 & $\begin{array}{l}\text { Badan Amil } \\
\text { Zakat } \\
\text { Nasional }\end{array}$ & $\begin{array}{l}\text { Funding } \\
\text { Distribution }\end{array}$ & $\begin{array}{c}158.752 .636 .318,85 \\
82.090 .491 .624 .00\end{array}$ & $\begin{array}{l}195.092 .051 .942,01 \\
175.811 .470 .985 .00\end{array}$ & $\begin{array}{l}22,89 \\
114,27\end{array}$ \\
\hline 2 & Rumah Zakat & $\begin{array}{l}\text { Funding } \\
\text { Distribution }\end{array}$ & $\begin{array}{l}227.144 .420 .906 \\
213.984 .714 .742 \\
\end{array}$ & $\begin{array}{l}232,867,662,297 \\
212,712,843,237 \\
\end{array}$ & $\begin{array}{c}2,52 \\
-0,59 \\
\end{array}$ \\
\hline 3 & LAZIS NU & $\begin{array}{l}\text { Funding } \\
\text { Distribution }\end{array}$ & $\begin{array}{l}200.311 .297 .875 \\
192.347 .152 .444\end{array}$ & $\begin{array}{l}294.859 .161 .476 \\
286.298 .761 .298\end{array}$ & $\begin{array}{l}47,20 \\
48,84\end{array}$ \\
\hline 4 & $\begin{array}{l}\text { Iniziatif } \\
\text { Zakat } \\
\text { Indonesia }\end{array}$ & $\begin{array}{l}\text { Funding } \\
\text { Distribution }\end{array}$ & $\begin{array}{l}61,111,555,924 \\
55,686,545,537\end{array}$ & $\begin{array}{l}90.478 .185 .214 \\
89.479 .481 .462\end{array}$ & $\begin{array}{l}48,05 \\
60,68\end{array}$ \\
\hline 5 & DPU DT & $\begin{array}{l}\text { Funding } \\
\text { Distribution }\end{array}$ & $\begin{array}{c}107,819,566,772 \\
96,258,926,801\end{array}$ & $\begin{array}{l}126,806,597,572 \\
123,296,276,102\end{array}$ & $\begin{array}{l}17,61 \\
28,09\end{array}$ \\
\hline
\end{tabular}

The data above shows the development of Islamic Economic Institutions or social institutions, which collect funds from several Islamic Social Institutions, which receive and distribute social funds used in several segments, including economic empowerment. The development of five Amil Zakat institutions that have received permits from the government, namely the National Zakat Agency (BAZNAS), Rumah Zakat, Lazis NU, Indonesian Zakat Initiative (IZI), and Dompet Caring for Ummat Daarut Tauhid (DPU DT) in the period 2017 to 2018 Development of revenue and distribution of social funds for the benefit of the community. From the data above, the receipt of social funds consisting of Zakat, Infaq / Sadaqah, Waqf, Grants, and others, the most significant development in the largest Indonesian Zakat initiative (IZI), reached 60.68 percent. Then the minor revenue from Rumah Zakat institution is 2.5 percent. Then the most extensive distribution of social funds is the National Zakat Agency (BAZNAS) at 114.27 percent, and the distribution has decreased at Rumah Zakat -0.59 percent. 


\section{The Role of Islamic Economic Institutions in Recovery of the Real Sector of SMEs}

Islamic economics is an economic system that carries out its activities based on sharia principles. The Islamic economy prioritizes the real sector and supports the financial sector for economic activity, including for the real sector. Islamic economics has many institutions today, both for bank and non-bank institutions based on sharia. Islamic economic institutions are widely used today, so they are essential in carrying out economic activities. Islamic economic institutions also have institutions for the micro sector and have economic institutions that are social in developing the economy. Islamic financial institutions have a role in the economic recovery, which is currently affected by economic movements amid the conditions of the Covid-19 pandemic.

Islamic economic institutions have a role in restoring SMEs amid the covid-19 outbreak through various products and services owned by Islamic economic institutions. BPRS can provide productive financing for SMEs with easier access and provide relief for customers affected by Covid-19 and supply SMEs support in marketing, especially utilizing technology for financing customers who are constrained by marketing through technology. BMT / microfinance institutions, together with BPRS, can optimize financing for the micro sector and assist SMEs players who become BMT customers to provide input and support in running a business. Then the P2P landing type Sharia Fintech institution can increase distribution for MSME businesses, provide convenience for partners affected by SMEs, assist SMEs players, and provide product marketing services through online facilities owned by sharia P2P landing.

Furthermore, Islamic economic institutions that are social in the development of SMEs. Islamic socio-economic institutions can channel their social funds for distribution to the economic sector of SMEs, which can provide easy access to obtain working capital or business capital. Social funds from socio-economic institutions can be channeled for humanitarian emergency activities and the empowerment and development of SMEs. It is a social nature in which the recipients of the funds will use the funds to empower SMEs businesses. In the covid-19 condition, it impacts the economy, especially SMEs. In this condition, Islamic economic institutions can play a role in restoring the activities in the real sector of SMEs. Both commercial Islamic economic institutions and social institutions. 


\section{Conclusion}

The development of Islamic economic institutions today, especially those that drive the economy, especially for the development of the real sector of SMEs. Sharia People's Financing Bank (BPRS), Baitul Maal Wattamwil (BMT)/ Sharia Microfinance Institutions, Sharia Fintech, and Social Institutions, Collectors and Distribution of Zakat, Infaq, Shadaqoh, and others. BPRS in the period January to May 2020 grew by 349.34 percent for income and experienced a decrease in the component of third-party funds by 2.53 percent. Sharia Microfinance Institutions in the period January 2020 to May 2020 grew by 11.75 for financing and experienced a decrease in the placement of funds by - 1.95 percent. Growth in Islamic fintech institutions type P2P Landing sharia in the April 2020 period experienced a decline in assets of -0.05 percent, and social institutions experienced growth in social fund receipts by 48.05 percent. Distribution grew by 114.27 per cent at the Amil Zakat Agency National (BAZNAS).

Islamic economic institutions have a role in the recovery of the real sector economy, especially SMEs, due to the impact of the corona covid-19 virus outbreak. In these conditions, Islamic economic institutions can take a role in the recovery of the real sector of SMEs. This role is in controlling the distribution of financing for SMEs, mentoring businesses of affected customers, participating in marketing customer products through technology, and providing relief for affected customers. Impact and support and provide input from businesses and maximize profit sharing patterns and partnerships with customers. In the form of amil zakat, social institutions can distribute social funds for economic development and production activities. 


\section{References}

Ascraya \& Yumanita, D. (2005). Bank Syariah: Gambaran Umum. Jakarta: Pusat Pendidikan dan Studi Kebangsentralan (PPSK) Bank Indonesia.

Danupranata, G. (2006) Seri Ekonomi Islam 3. Yogyakarta : (UPFE UMY).

Darsono, etc. (2017). Masa Depan Keuangan Syariah Indonesia. Bogor: Tazkia Publishing.

Debby, P. \& Indrarini, R. (2017) Pembiayaan BPR Syariah Dalam Peningkatan Kesejahteraan UMKM Berdasarkan Maqashid Syariah. Jurnal Ekonomi dan Bisnis Islam, Vol. 3, No. 1, Januari-Juni 2017. Surabaya : Universitas Airlangga.

Fahmi, A. etc. (2014). HRD Syariah Teori dan Implemtasi. Jakarta: PT. Gramedia Pustaka Utama.

Fintech, T. G. (2017). Kajian Bisnis Fintech Syariah. Telkom Digital Services. https://doi.org/10.1111/j.1365-2966.2008.13419.x

Kementerian Perencanaan Pembangunan Nasional/Badan Perencanaan Pembangunan Nasional. (2018). Masterplan Ekonomi Syariah Indonesia 2019-2024 Hasil Kajian Analisis Ekonomi Syariah di Indonesia.

Khairani, M \& Marlina, E. (2017). Zakat Produktif dan Perannya terhadap Perkembangan UMKM Studi pada LAZ el-Zawa UIN Maulana Malik Ibrahim Malang, Seminar Nasional Peluang dan Tantangan Pengembangan UMKM dan Ekonomi Kreatifdalam Era Global dan Digital, Bali 5 Mei 2017, Undiknas.

Kholis, N. etc. (2013). Potret Filantropi Islam di Propinsi Daerah Istimewa Yogyakarta. Yogyakarta: Journal LaRiba Volume 7, Nomor 1, Departemen Of Islamic Economic, Universitas Islam Indonesia.

Kristian, A. P. (2020). COVID-19 dan Implikasi Bagi Usaha Mikro, Kecil, dan Menengah. Parahyangan : Jurnal Ilmiah Hubungan Internasional. Universitas Katolik Parahyangan. Volume Volume 16 Nomor 1. Universitas Katolik Parahyangan.

Law No. 21. About SMEs

Minarni. (2015). Falsifikasi Kebijakan Fiskal di Indonesia Perspektif Islam; Menemukan Relevansi Pemikiaran Ibnu Taimiyah Tentang Keuangan Publik Sebagai Potret Khasanah Kebijakan Fiskal Priode Klasik Islam. Yogyakarta: Graha Ilmu.

Muhamad. (2009). Model-model Akad Pembiayaan di Bank Syariah. Yogyakarta: UII Press Yogyakarta.

Muheramtohad, S. (2017). Peran Lembaga Keuangan Syariah dalam Pemberdayaan UMKM di Indonesia. Salatiga: Jurnal Muqtasid, Jurnal Ekonomi dan Perbankan Syariah. IAIN Salatiga Volume 8, Nomor 1.

Hubeis, M. (2009). Prospek Usaha Kecil Dalam Wadah Inkubator Bisnis, Cet.I. Bogor: Galia Indonesia.

Otoritas Jasa Keuangan. (2020) Statistic Of Sharia IKNB mounthly April 2020.

Otoritas Jasa Keuangan. (2020) Fintech Lending April 2020.

Otoritas Jasa Keuangan. (2020) Statistic Of Sharia Banking May 2020.

P3EI UII. (2008). Ekonomi Islam. Jakarta: PT. Raja Grafindo Persada.

Sofyan, R. (2011). Bisnis Syariah Mengapa Tidak? Jakarta: PT Gramedia Pustaka Utama.

Sudarsono, H. (2008). Bank Dan Lembaga Keuangan Syariah Deskripsi dan Ilustrasi Edisi 3. Yogyakarta: Ekonisia.

Sumitro, W. (2004). Azas-azas Perbankan Islam dan Lembaga-lembaga Terkait. Jakarta: Raja Grafindo Persada.

Syauqi, I.B \& Laily. D.A. (2016). Ekonomi Pembangunan Syariah. Jakarta: PT RajaGrafindo Persada.

Umam, K. \& Setiawan, B.U. (2017). Perbankan Syariah:Dasar-dasar dan Dinamika Perkembangannya di Indonesia. Jakarta: PT RajaGrafindo Persada. 
Wachyu, W.A.W. (2020). Peran Fintech dalam Usaha Mikro Kecil dan Menengah (UMKM). Sibolga: Jurnal Ekonomi \& Ekonomi Syariah Volume 3 Nomor 1. Sekolah Tinggi Ilmu Ekonomi (STIE) Al-Washliyah Sibolga.

https:/www.cnbcindonesia.com/news/20200429173402-8-155339/ini-kata-teten-masduki-soal-dampakcovid-19-bagi-umkm, Accessed 10 July 2020.

https://nasional.kontan.co.id/news/menghitung-dampak-covid-19-terhadap-dunia-usaha-hingga-umkm, Accessed 11 July 2020.

https://knks.go.id/isuutama/6/penyusunan-roadmap-pengembangan-baitul-maal-wat-tamwil-bmt-diindonesia, Accessed 14 July 2020.

https://sharianews.com/posts/menyongsong-perkembangan-bmt-di-indonesia, Accessed 16 July 2020. 